\title{
SYNTHESES AND CHARACTERISATION OF DIUREA MOLECULAR TWEESORS FOR THE RECOGNITION OF ANION
}

\author{
${ }^{1}$ R. C. JAGESSAR* \\ ${ }^{I *}$ Senior Lecturer, Department of Chemistry, University of Guyana, Turkeyen campus, Greater Georgetown, South America. \\ (Received: March 13, 2013 - Accepted: June 25, 2013)
}

\begin{abstract}
Two novel urea anion receptors (11) and (12) were synthesized from building block 3,3' methylene diamine and was characterized via the techniques of ${ }^{1} \mathrm{H}$ NMR, ${ }^{13} \mathrm{C}$ NMR, DEPT- $135{ }^{1} \mathrm{H}-{ }^{1} \mathrm{H}$ COSY, HMQC and HMBC spectroscopy. The ${ }^{1} \mathrm{H}$ NMR profile of both compounds reveals diagnostic peaks. For compound (11), the urea NH protons resonate as two singlets downfield at $8.706 \mathrm{ppm}$ and $8.635 \mathrm{ppm}$, whereas for compound (12) these two urea -NHCONH protons resonate together at $8.614 \mathrm{ppm}$. There seem to be no rotation of the structure on the NMR time scale as the bridged $\mathrm{CH}_{2}$ protons resonate as a singlet. The integration pattern for the aromatic hydrogens for both compounds is: $2: 4: 2: 4: 4$, consistent with the structure. ${ }^{13}$ CNMR spectrums reveal fourteen signals for both structures in accordance with fourteen different types of carbon. Dept-135 indicates eight different $\mathrm{CH}$ protons. Preliminary anion binding studies via ${ }^{1} \mathrm{HNMR}$ spectroscopy revealed complexation with dicarboxylate anions in the highly competitive solvent, $\mathrm{d}_{6}$-DMSO.
\end{abstract}

Keywords: Novel urea receptors, 3,3'-methylene diamine scaffold, spectroscopic techniques, integration pattern, dicarboxylate anion

\section{INTRODUCTION}

The molecular recognition of anions is a current, active and difficult area of Supramolecular chemistry, considering the ubiquitious properties of anions ${ }^{1-5}$. Anions play pivotal roles in biological, environmental and Supramolecular sciences $^{1-28}$. Of great interest is the design, syntheses and use of neutral receptors for selective binding of anions $s^{6-27}$. Also, such receptors present a balance between rigidity and flexibility, an important feature in designing a host for encapsulation of a substrate. In designing an anionic host, charge and shape complementarity between the host and anionic guest are of paramount importance ${ }^{1-5}$. Most anion receptors reported to date are macrocyclic in nature ${ }^{1-5,6-28}$

Anion recognition by hydrogen bonding urea-based receptors is a relatively new motif of anion coordination Supramolecular Chemistry ${ }^{25-27}$. The efficiency of urea as an anion receptor subunit depends on the presence of two proximate polarised $\mathrm{N}-\mathrm{H}$ moities, capable of chelating a spherical anion and also donating two parallel H-bonds to the oxygen atoms of a carboxylate or of an inorganic oxoanion, a property which is also shared with other diamides such as squaramide. The urea functionality is usually synthesise via the reaction of a primary amine group with an isocyanate in significant yields ${ }^{25-27}$. Both symmetrical and unsymmetrically substituted derivatives can be synthesised. Neutral receptors of urea, thiourea and amides are of further significance because the transport of anions such as phosphate, $\mathrm{PO}_{4}{ }^{3}$ - anion through cell membranes is regulated by neutral binding proteins ${ }^{9-15}$. Also, neutral anion receptors, especially those of the amido type exploit hydrogen bonding interactions with anions and are found in biological systems. Depending on their spatial orientation (geometry), neutral amides are expected to selectively complex guest substrates ${ }^{12-14,20-24}$. There are several reports of anion recognition by urea receptors ${ }^{15-19,25-27}$. For example, A bis-urea and a bis-thiourea host (1), both derived from 1,3-bis(aminomethyl)benzene have been shown to bind dihydrogenphosphate selectively over various other anions according to the selectivity trend: $\mathrm{H}_{2} \mathrm{PO}_{4}^{-}>\mathrm{CH}_{3} \mathrm{COO}^{-}>\mathrm{Cl}^{-}>\mathrm{HSO}_{4}^{-}>\mathrm{NO}_{3}^{-}>\mathrm{ClO}_{4}^{-}$. The much stronger binding of $\mathrm{H}_{2} \mathrm{PO}_{4}^{-}$by the bis-thiourea is due to the stronger $\mathrm{H}$-bond donor strength of the thiourea groups, Figure 1.0. Binding selectivity is explained in terms of the complex geometry and the basicity of the guest anions. The lack of self-association was also an added advantage of this relatively novel class of receptor for dihydrogen phosphate.

Benzimidazolium urea anion based receptors have been designed and synthesized ${ }^{26}$. On the basis of fluorescence, UV-Vis, ${ }^{1} \mathrm{H}$ NMR spectroscopic studies and X-ray single crystal structure analyses, it was confirmed that the receptor displays strong $(\mathrm{C}-\mathrm{H})^{+} \ldots \mathrm{X}, \mathrm{N}-\mathrm{H} . . . \mathrm{X}$ hydrogen bonds and chargecharge interactions with anions. More importantly, these investigations demonstrated that the charged $(\mathrm{C}-\mathrm{H})^{+}$benzimidazolium and urea moieties play a synergistic role in anion recognition.

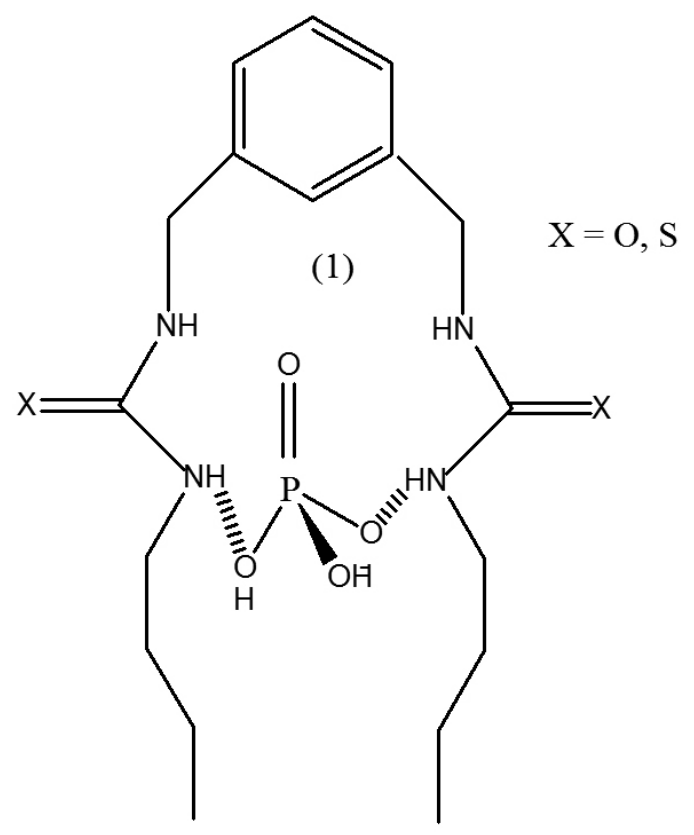

Figure 1. bis urea and bis thio urea anion receptors.

A neutral urea anion receptor (2) with a tripodal pseudocavity was synthesized in good yield ${ }^{27}$ (Figure 2) The influence of preorganization and rigidity of the receptors towards anion recognition was evaluated using rigid and flexible unit receptors. Binding affinities were investigated using ${ }^{1} \mathrm{H}$ NMR and luminescence titration methods. Receptor (2) showed high binding affinities with 1:1 stoichiometry for aromatic carboxylate anions in polar solvents. No binding was observed with small anions, due to the large cavity and the rigidity of the receptor. The obtained results are explained based on the rigidity and preorganization of the receptor.

Neutral porphyrin urea anion receptors (3)-(6) and their corresponding zinc complexes (7-9), exploiting the neutral urea binding motif and in case of the zinc complexes, Lewis acid interactions have been reported ${ }^{16-17}$ (Figure 2). Significantly large association constants have been reported for these compounds binding to anion in highly competitive solvents such as $\mathrm{d}_{6}$-DMSO. For example neutral free base porphyrin urea anion receptors (3) - (6) selectively complex halides anions over phosphate with association constant of $1 \times 10^{5} \mathrm{M}^{-1}$ in $\mathrm{d}_{6}$-DMSO ${ }^{16-17}$. The a,a,a,a-5,10,15, 20 meso tetrakis-(2-(arylurea)phenyl) porphyrins bind strongly $\left.\left(\mathrm{K}_{(\mathrm{M}}^{-1}\right)>10^{3}-10^{5}\right)$ to chloride and bromide anion in DMSO- $\mathrm{d}_{6}$ and in DMSO- $\mathrm{d}_{6} / \mathrm{D}_{2} \mathrm{O}(88: 12, \mathrm{v} / \mathrm{v})$ as revealed by ${ }^{1} \mathrm{H}$ NMR titration 
studies. These porphyrin derivatives exhibited significant binding selectivity since they complexed with the spherical $\mathrm{Cl}^{-}$and $\mathrm{Br}^{-}$to a much greater extent than with the tetrahedral $\mathrm{H}_{2} \mathrm{PO}_{4}^{-}, \mathrm{HSO}_{4}^{-}$and trigonal $\mathrm{NO}_{3}^{-}$anions in DMSO-d binding systems. The corresponding zinc complexes also show a decrease in binding constant and selectivity.

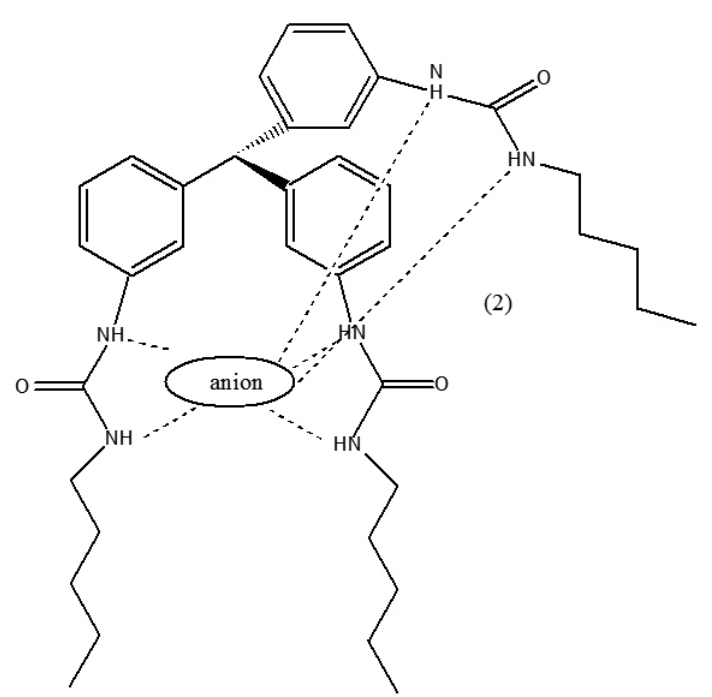

Figure 2. A tripodal urea anion receptor.

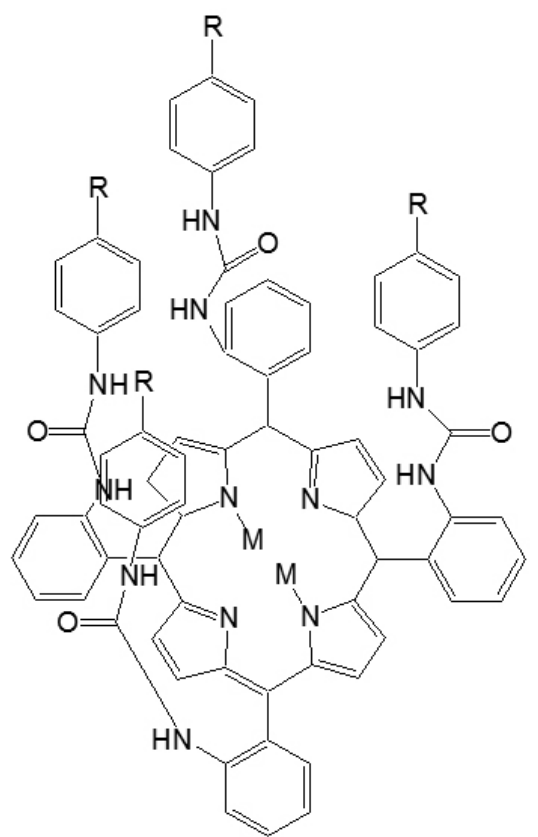

$\mathrm{M}=\mathrm{M}=\mathrm{H}$

$$
\begin{array}{ll}
\mathrm{R}=\mathrm{H},(3) & \mathrm{M}, \mathrm{M}=\mathrm{Zn} \\
\mathrm{R}=\mathrm{Cl},(4) & \mathrm{R}=\mathrm{H}(7), \mathrm{R}=\mathrm{Cl}(8), \mathrm{R}=\mathrm{F}(9) \\
\mathrm{R}=\mathrm{F},(5) & \\
\mathrm{R}=\mathrm{NO}_{2}(6) &
\end{array}
$$

Figure 3. Porphyrin Urea anion receptors and their corresponding metal complexes.
This paper focuses on the syntheses, characterization and preliminary anion binding studies of molecular clef type urea receptors (11) and (12) incorporating the urea, -HNCONH- moieties. These receptors are built on the molecular scaffold of 3,3' methylene diamine and present convergent binding sites to anionic substrates.

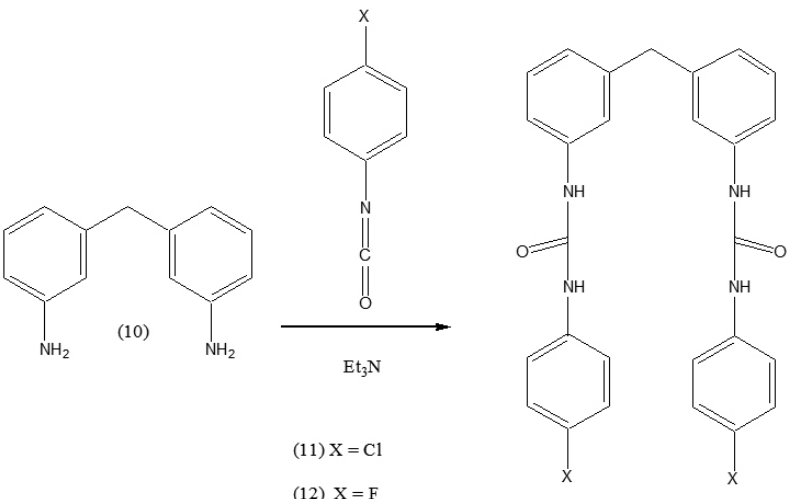

(11) $; \mathrm{X}=\mathrm{Cl}$

(12); $\mathrm{X}=\mathrm{F}$

Scheme 1. synthesis of urea anion receptors

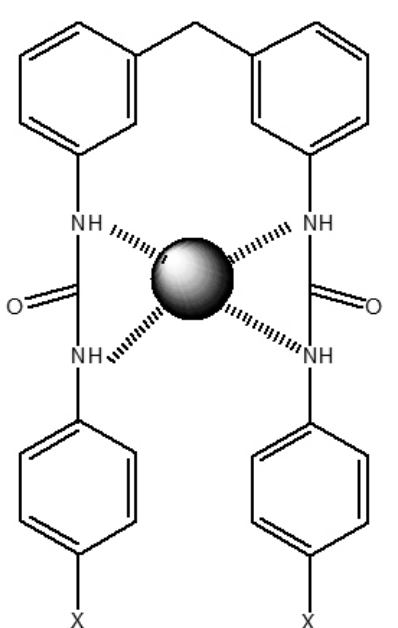<smiles></smiles>

Figure 4. Proposed mode of anion binding for a spherical chloride ion and a dicarboxylate anion by urea anion receptors (11) and (12).

\section{EXPERIMENTAL}

\section{Synthesis}

$\left(0.40 \mathrm{~g}, 2.02 \times 10^{-3} \mathrm{~mol}\right)$ of the diamine was dissolved in $50 \mathrm{ml}$ of $\mathrm{CHCl}_{3}$ in a $100 \mathrm{ml}$ RB flask. The reaction mixture was left stirring for 15 minutes under nitrogen. To this solution was added the 4-chlorophenyl $(0.59 \mathrm{~g}, 3.883 \mathrm{x}$ $\left.10^{-3} \mathrm{~mol}\right)$ or 4 -fluorophenyl isocyanate $(0.0044,0.68 \mathrm{~g})$. The reaction changed colour after 5 minutes to a white curdy nature. It was left stirring for $24 \mathrm{hrs}$ after which the precipitate was filtered. The product was then taken up in $\mathrm{H}_{2} \mathrm{O}$, stirred and filtered. The yield of compound (3) and (4) were $(0.94 \mathrm{~g}, 92.19 \%)$ and $(0.82 \mathrm{~g}, 83.93 \%)$ respectively.

\section{Characterisation:}

Compound (3), $\mathrm{C}_{27} \mathrm{H}_{22} \mathrm{O}_{2} \mathrm{Cl}_{2} ;{ }^{1} \mathrm{HNMR}(300 \mathrm{MHz}) \mathrm{d}: 3.859$ (s, $\left.\mathrm{CH}_{2}\right), 6.865$ (d; $2 \mathrm{H} ; \mathrm{J}=6.9 \mathrm{~Hz}, \mathrm{ArH}), 7.083-7.128(\mathrm{~m}, 4 \mathrm{H} ; \mathrm{ArH}), 7.22-7.128(\mathrm{~m}, 2 \mathrm{H} ; \mathrm{ArH})$ 7.181-7.278 (m, 4H. ArH), 7.305-7.276 (m, 4H, ArH), 7.437-7.464 (d; 4H; J $=8.1 \mathrm{~Hz}, \mathrm{ArH}), 8.61(\mathrm{~s}, 4 \mathrm{H} ; \mathrm{NHCONH}) ;{ }^{13} \mathrm{C} \mathrm{NMR}(400 \mathrm{MHz}) \mathrm{d}: 155.06(\mathrm{CO})$, 144.47 (ipso-C-Ar), 142.30 (ipso-C-Ar), 141.38(ipso-C-Ar), 140.24, 131.52 
(CH-Ar), 131.28 (CH-Ar), 128.03 (ipso-C-Ar), $125.23(\mathrm{Ar}-\mathrm{CH}), 122.42(\mathrm{Ar}-$ $\mathrm{CH}), 121.24$ (Ar-CH), 119.25 (Ar-CH), 118.76 (Ar-CH), 44. $02\left(\mathrm{CH}_{2}\right)$; Dept 135: 131.53, 131.28, 125.22, 122.40, $121.22119 .25,118.74,40.43\left(\mathrm{CH}_{2}\right)$; ${ }^{1} \mathrm{H}-{ }^{1} \mathrm{H}$ COSY: H-1/H-2, H-3; H-2/H-1, H-3; H-3/H-2/H-1; H-8/H-9; H-9/H-8; $\mathrm{H}-10 / \mathrm{H}-11$; H-11/H-10; HMBC: H-1/C-3, C-4; H-2/C-4; H-3/C-1, C-4; H-5/C-1, C-4; H-8/C-10, H-9/C-11, H-10/C-8, H-11/C-9; FABMS: CALCD for $\mathrm{C}_{27} \mathrm{H}_{22} \mathrm{O}_{2} \mathrm{Cl}_{2} \mathrm{~N}_{4} ; 505.39$; Found: 505.39

Compound (4): $\mathrm{C}_{27} \mathrm{H}_{22} \mathrm{O}_{2} \mathrm{~F}_{2} ;{ }^{1} \mathrm{HNMR}(400 \mathrm{MHz})$ d: 3.859 (s; $\left.\mathrm{CH}_{2}\right), 6.865-$ 6.847 (d; $2 \mathrm{H} ; \mathrm{J}=7.2 \mathrm{~Hz}, \mathrm{ArH}), 7.106-7.083$ (d, 2H; J = 9.2Hz, ArH), 7.128$7.106(\mathrm{~d}, 2 \mathrm{H} ; \mathrm{J}=8.8 \mathrm{~Hz}, \mathrm{Ar}-\mathrm{H}), 7.220-7.201(\mathrm{~m}, 2 \mathrm{H} ; \mathrm{Ar}-\mathrm{H}), 7.320-7.278(\mathrm{~m}$, 4H; Ar-H), 7.462-7.428 (m, 4H; ArH), 8.635 (s, NH-CO-NH; 2H), 8.71 (s, 2H; NHCONH); ${ }^{13} \mathrm{CNMR}(400 \mathrm{MHz})$ d: 153.03 (CO), 142.23 (ipso-C-Ar), 140.24 (ipso- C-Ar) 136.48 (ipso -C-Ar), 136.45 (ipso-C-Ar) ,129.27 (Ar-CH), 122.85 ( $\mathrm{Ar}-\mathrm{CH}), 120.48(\mathrm{Ar}-\mathrm{CH}), 120.37$ (Ar-CH), $118.93(\mathrm{Ar}-\mathrm{CH}), 116.44(\mathrm{Ar}-\mathrm{CH})$, 115. 85 (Ar-CH), $115.55(\mathrm{Ar}-\mathrm{CH}) 41.80\left(\mathrm{CH}_{2}\right)$; DEPT $(400 \mathrm{MHz}) \mathrm{d}: 127.90$ $(\mathrm{Ar}-\mathrm{CH}), 121.47$ (Ar-CH), 119.10(Ar-CH), 119(Ar-CH), 117.55( $\mathrm{Ar}-\mathrm{CH})$, 115.06 (Ar-CH), 114.47( $\mathrm{Ar}-\mathrm{CH}), 114.18(\mathrm{Ar}-\mathrm{CH}), 44.01\left(\mathrm{CH}_{2}\right) ;{ }^{1} \mathrm{H}-{ }^{-1} \mathrm{H}$ COSY: (H-1/H-2, H-3; H-2/H-1,H-3; H-3/H-2, H-1; H-4/H-3; H-8/H-9; H-10/H-11; HMQC:H-1/115.85, H-2/120.48; H-3/122.85; H-8/115.55; H-9/120.37; HMBC:H-1/C-2,C-3,C-4; H-2/C-1, C-3, C-4; H-3/C-2, C-1, C-4; H-4/C-2, C-1, C-5; H-8/C-10, H-9/C-10, C-11; FABMS: CALCD for $\mathrm{C}_{27} \mathrm{H}_{22} \mathrm{O}_{2} \mathrm{~F}_{2} \mathrm{~N}_{4}$; 472.49; Found: 472.00

\section{RESULTS AND DISCUSSION}

Compounds (11) and (12), described as diurea molecular tweezers are built on the building block, 3,3' methylene diamine. Both compounds (11) and (12), spectroscopic integrity were established via ${ }^{1} \mathrm{H}$ NMR, ${ }^{13} \mathrm{C}$ NMR, DEPT-135, ${ }^{1} \mathrm{H}-{ }^{1} \mathrm{H}$ COSY, HMQC and HMBC spectroscopic techniques. ${ }^{1} \mathrm{H}-$ ${ }^{1} \mathrm{H}$ COSY shows protons/protons connectivity, HMQC shows the connectivity of individual protons to carbon and HMBC also shows the connectivity of protons to two or more carbon away. Using all these spectroscopic techniques, compounds (11) and (12) were characterized.

The ${ }^{1} \mathrm{H}$ NMR profile of both compounds reveals diagnostic peaks. The spectrum of both compounds can be compared. For compound (11), the urea $\mathrm{NH}$ protons resonate as two singlets downfield at $8.706 \mathrm{ppm}$ and $8.635 \mathrm{ppm}$. For compound (12) these two urea $-\mathrm{NHCONH}$ protons resonate at 8.614 ppm.Urea protons for compound (11) seems to be more upfield than that for compound (12). Methylene $\mathrm{CH}_{2}$ protons show singlet resonance at 3.873 $\mathrm{ppm}$ and $3.859 \mathrm{ppm}$ for (11) and (12) respectively, suggesting that there is no conformational rotation about the $\mathrm{CH}_{2}$ unit of the 3,3' methylene dianiline scaffold on the NMR timescale. For compound (11), aromatic protons resonate in the region $6.837 \mathrm{ppm}$ to $7.464 \mathrm{ppm}$ whereas for compound (12) this is seen at 6.847 to $7.462 \mathrm{ppm}$.

For compound (11), four sets of aromatic signals were obtained. The integration pattern for the aromatic hydrogens been $2: 2: 8: 4$, consistent with the structure $(16 \mathrm{H})$. Aromatic protons $\mathrm{H}-4$ on ring $\mathrm{A}$ and $\mathrm{B}$ resonate as a virtual doublet at $6.837 \mathrm{ppm}(\mathrm{J}=6.9 \mathrm{~Hz})$ whereas $\mathrm{H}-2$ and $\mathrm{H}-3$ resonate together as a multiplet and this is seen at $7.28 \mathrm{ppm}(4 \mathrm{H})$. Protons $\mathrm{H}-1(2 \mathrm{H})$ are seen as a virtual triplet at $7.16 \mathrm{ppm}(\mathrm{J}=7.2 \mathrm{~Hz})$, resulting from an $\mathrm{AB}$ type coupling. Protons on ring $\mathrm{C}$ and $\mathrm{D}, \mathrm{H}-8$ and $\mathrm{H}-9$ resonate as a doublet $(4 \mathrm{H})$ and this is seen at $7.437 \mathrm{ppm}(\mathrm{J}=8.1 \mathrm{~Hz})$. The doublet resonance for protons $\mathrm{H}-10$ $(2 \mathrm{H})$ and $\mathrm{H}-11(2 \mathrm{H})$ is seen at $7.276 \mathrm{ppm}(\mathrm{J}=8.7 \mathrm{~Hz})$ and respectively. Urea $-\mathrm{NHCONH}-$ protons are seen as two doublets at 8.71 and $8.64 \mathrm{ppm}$. Urea, $\mathrm{NHCONH}$ protons for compound (11) seem to be more upfield than urea protons for compound (12).

For compound (12), five sets of aromatic resonances were seen. Protons on ring $\mathrm{C}$ and $\mathrm{D}, \mathrm{H}-8$ and $\mathrm{H}-9$ are seen as two sets of doublets. The integration pattern for the aromatic hydrogens been $2: 4: 2: 4: 4$ consistent with the number of aromatic hydrogens $(16 \mathrm{H})$ for the structure. One set of doublet $(2 \mathrm{H})$ is seen at peak $3,7.18 \mathrm{ppm}(\mathrm{J}=8 \mathrm{~Hz})$ for $\mathrm{H}-8$ and the other couple proton $(\mathrm{J}=8.0 \mathrm{~Hz})$ is seen at peak (4), $7.28 \mathrm{ppm}$ for $\mathrm{H}-9(2 \mathrm{H})$. Likewise two sets of doublets are seen for protons $\mathrm{H}-10$ and $\mathrm{H}-11$. Each proton is split by one another to yield two doublets. One of these is seen at peak (2), $7.08 \mathrm{ppm}$, the other couple proton $(\mathrm{J}=8.8 \mathrm{~Hz})$ is seen in peak $(4)$ at $7.28 \mathrm{ppm}$. Protons $\mathrm{H}-1$ and $\mathrm{H}-2(4 \mathrm{H})$ resonate together as two virtual triplets at $7.428 \mathrm{ppm}(\mathrm{J}=4.8 \mathrm{~Hz} ; \mathrm{J}=5 \mathrm{~Hz})$. Proton $\mathrm{H}-3(2 \mathrm{H})$ also resonate as a virtual triplet at $7.128 \mathrm{ppm}(\mathrm{J}=9.2 \mathrm{~Hz})$ in peak 2. Aromatic protons $\mathrm{H}-4$ shows a small coupling interaction and resonate as a virtual doublet $(\mathrm{J}=7.2 \mathrm{~Hz})$ at $6.865 \mathrm{ppm}$.

${ }^{13}$ CNMR spectrums reveal fourteen signals for structures (11) and (12), in accordance with fourteen different types of carbon. For compound (11) these resonate at $(155.06,144.47,142.30,141.38,131.52,131.28,128.03$ $125.23,122.42,121.24,119.25,118.76$ and $44.02 \mathrm{ppm}$. Dept 135 indicates aromatic $\mathrm{CH}$ protons at $(131.53,131.28,128.03,125.23,122.40,121.24$, $119.25,118.76$ and $\mathrm{CH}_{2}$ protons at $44.01 \mathrm{ppm}$ ). Ipso resonances are seen at $(144.47,142.30,141.38$ and 128.03) ppm. The carbonyl carbon resonate far downfield at $155.06 \mathrm{ppm}$. Compound (12) fourteen carbon signals are seen at $(153.03,142.23,140.24,136.48,136.45,129.27,122.85,120.48,120.37$, $118.93,116.44,115.85,115.55 \mathrm{ppm}$. Dept 135 indicates aromatic $\mathrm{CH}$ protons at $129.27,122.85,120.48,120.37,118.93,116.44,115.85,115.55,115.0$. The $\mathrm{CH}_{2}$ carbon is seen at $40.43 \mathrm{ppm}$.

${ }^{1} \mathrm{H}-{ }^{1} \mathrm{H}$ COSY experiments revealed ${ }^{1} \mathrm{H}-{ }^{1} \mathrm{H}$ connectivity. For example, $\mathrm{H}-1$ proton (on ring A) couples with $\mathrm{H}-2$ and $\mathrm{H}-3$ protons i.e shows cross peaks which are in line with those for $\mathrm{H}-2$ and $\mathrm{H}-3$. H-8 couples with $\mathrm{H}-9$ and $\mathrm{H}-10$ couples with $\mathrm{H}-11$ on ring $\mathrm{C}$ and $\mathrm{D}$. Methylene, $\mathrm{H}-5$ protons shows no ${ }^{1} \mathrm{H}-{ }^{-1} \mathrm{H}$ connectivity and thus resonate as a singlet upfield. Urea - $\mathrm{NHCONH}$ - protons show no coupling interaction with aromatic protons of the phenyl ring.

HMBC shows the connectivity of protons to two or more carbon away and these are presented in the experimental section.

Preliminary anion complexation studies with dicarboxylate anion in $\mathrm{d}$ DMSO revealed significant downfield shifts in the host urea- NHCONHprotons. Shifts greater than $1.2 \mathrm{ppm}$ were observed after the addition of one equivalent of anion. This indicates significant urea $-\mathrm{NHCONH}$ - hydrogen bonding interactions amongst other non-covalent interactions contributing to the overall anion binding process (Figure 4 and 5).

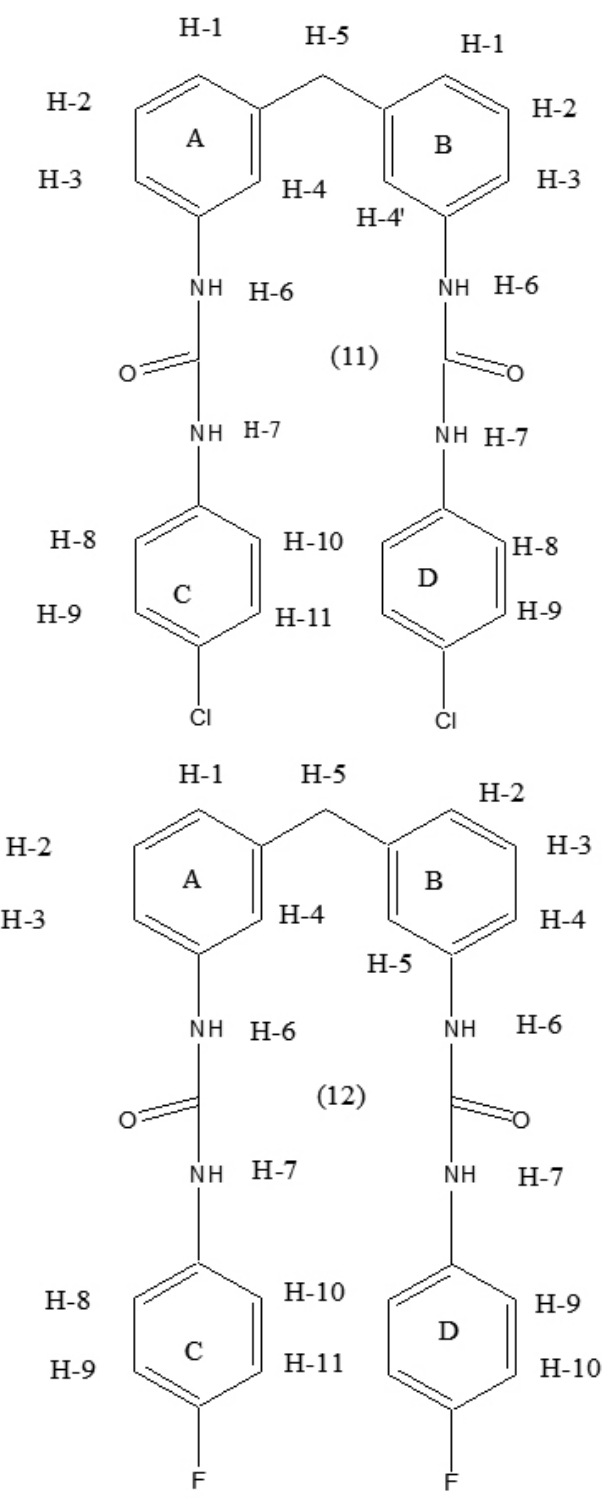

Figure 5. Shows the proposed mode of anion binding of receptor (11) and (12) to a dicarboxylate anion. 


\section{CONCLUSIONS}

Two novel urea anion receptors based on the 3,3' methylene diamine molecular scaffold have been synthesized and characterized using conventional contemporary spectroscopic techniques. Preliminary anion binding studies revealed complexation to linear dicarboxylate anion in the highly competitive $\mathrm{d}_{6}$-DMSO solvent medium.

\section{ACKNOWLEDGEMENTS}

This project was finally supported by Dr. R.C. Jagessar. Spectroscopic data were collected overseas

\section{REFERENCES}

1. J.M, Lehn, Supramolecular Chemistry: Concepts and Perspectives. $\left(1^{\text {st }}\right.$ ed.). New York, Wiley-VCH, (Chapter 3), (1995).

2. Supramolecular Chemistry of Anions; Wiley-VCH: New York, (1997).

3. F.P. Schmidtchen, M. Berger, Artificial Organic Host Molecules for Anions: Chem. Rev. 97, 1609-1646, (1997).

4. P.D. Beer, Transition-Metal Receptor Systems for the Selective Recognition and Sensing of Anionic Guest Species., Acc. Chem. Res. 31 (2), 71-80, (1998).

5. K. Bowman-James, The Coordination Chemistry of Anions, Acc. Chem. Res. 38, 671-678, (2005).

6. R, Martinez-Manez, F, Sancenon, Fluorogenic and chromogenicchemosensors and reagents for anions, Chem. Rev., 103, 4419-4476, (2003).

7. F. Sancenon, A.B. Descalze, M.A. Miranda, J. Sato, A colorimetric ATP sensor based on 1,3,5-triarylpent-2-en-1,5-diones, Angew. Chem., Int. Ed., 40, 2640, (2001).

8. T. Gunnlaugason, A.P. Davis, J.E. O’Brien, M. Glynn, (2002). Fluorescent sensing of Pyrophosphate and Bis-carboxylates with charge neutral PET chemosensors., Org. Lett.. 4, 2449, (2002).

9. G. Hennrich, H. Sonnennachein, L. Reach-Genger, Tetrahedron Lett., 42, 2805, (2001).

10. K. Choi, A.D. Hamilton, Macrocyclic anion receptors based on directed hydrogen bonding interaction, Coordination Chem. Rev, 240, 101-110, (2003).

11. S.L Wiskur, H. Ait-Hissou, J.J Lavigne, E.V. Anslyn, Teaching Old Indicators New Tricks, Acc. Chem. Res. 34, 963-972, (2001).

12. L. Kuo, J.H. Liao, C.T. Chen, C.H. Huang, C.S. Chen, J.M. Fang, Two Arm Ferrocene Amide Compounds: Synclinal Conformations for Selective Sensing of Dihydrogen Phosphate ion, Organic Letters, 5 (11), 1821-1824, (2003)

13. S. Kubic, R. Goddard, R. Kirchner, D. Nolting, Seidel., Recognition of Anions, J. Angew. Chem. Int. Ed., 40, 2648, (2001).
14. I.V. Korendovych, M. Cho, L.P. Butler, J.R. Staples, E.V.R. RybakAkimova, Anion binding to monotopic and ditopic macrocyclic amides, Organic letters. 8(15):3171-4, (2006).

15. J. Schearder, J.F.J Engbersen, A. Casnati, R. Ungaro, D. N. Reinhoudt, Complexation of halide Anions and Tricarboxylate anions by Neutral Urea Derivatives, p-tert-butylcalix[6]arene, J.Org. Chem., 60, 6448-6454, (1995).

16. R.C Jagessar, M. Shang, W.R Scheidt, D. H Burns, Neutral Ligands for selective Chloride Anion Complexation: (a,a,a,a) (Cis)-5,10,15,20 -Tetrakis (2-(arylurea) phenyl porphyrins: J. Am.Chem.Soc., 120 (45), 11684-11692, (1998)

17. R.C Jagessar, D. H. Burns, (Cis)-5,10,15,20 -Tetrakis (2-(arylurea) phenyl porphyrins: Novel neutral ligands for remarkablely selective and exceptionally strong chloride anion complexation in $\left(\mathrm{CD}_{3}\right)_{2} \mathrm{SO}, J$. Chem. Soc., Chem. Commun., 1685 - 1686, (1997).

18. S. Amemiya, P. Buhlmann, Y. Umezawa, R. C._Jagessar, D. H. Burns, An ion-selective electrode for acetate based on a urea-functionalized porphyrin as a hydrogen bonding ionophore, Anal Chem., 71(5), 1049 1054, (1999).

19. P. D Beer, A. R Graydon, L. R Sutton, Luminescent anion recognition selective induced emission by binding of dihydrogenphosphate. Polyhedron, 15 (14), 2457-2461, (1996).

20. Z. Chen, A.R. Graydon, P.D. Beer, Electrochemical response to anions in acetonitrile by neutral molecular receptors containing ferrocene, amide and amine moieties., J. Chem. Soc., Faraday Trans. 92(1), 97-102, (1996).

21. P.D. Beer, M.G.B. Drew, D.K Smith, Selective electrochemical recognition of bidentate anionic guests in competitive solvents using novel ferrocenyl thiourea and guanidinium receptors. J. Organomet. Chem. 543 (1-2), 259-261, (1997)

22. P.D. Beer, M.G.B. Drew, R. Jagessar, (1997)._Selective anion recognition by Novel 5, 10, 15, 20 - tetrakis (o-ferrocenyl carbonylaminophenyl - substituted) zinc metalloporphyrin receptors, J. Chem. Soc., Dalton Trans., $881-886,(1997)$.

23. P.D. Beer, M.G.B Drew, D. Hesek, R. Jagessar, Spectral and Electrochemical Anion Sensing by a novel 5,10,15,20-tetrakis(Rsubstituted)Porphyrin Receptor $\left(\mathrm{R}=\mathrm{C}_{6} \mathrm{H}_{4} \mathrm{NHC}(\mathrm{O}) \mathrm{C}_{5} \mathrm{H}_{4} \mathrm{CoC}_{5} \mathrm{H}_{5}{ }^{+} \mathrm{PF}_{6}{ }^{-}\right), \quad J$. Chem. Soc.,Chem.Commun., 1187-1189, (1995).

24. V. Amendola, L. Fabbrizzi, L. Mosca, Anion recognition by hydrogen bonding: urea-based receptors, Chem. Soc. Rev., 39, 3889-3915, (2010).

25. S. Nishizawa, P. Bühlmann, M. Iwao, Y. Umezawa, Anion Recognition by Urea and Thiourea Groups: Tetrahedron Lett. 36, 6483-6486, (1995).

26. A. Fan, H.K Hong, S. Valiyaveettil, J.V. Jagadese, A Urea-Incorporated Receptor for Aromatic Carboxylate Anion Recognition, Journal of Supramolecular Chemistry, 2 (1-3), 247-254, (2002).

27. Z.Y. Dong, G. H. Gao, Recognition and sensing of anions through synergistic effects using simple benzimidazolium-urea receptors, Chinese Science Bulletin, 57 (11), 1266-1274, (2012). 